Tersedia online di: http://ejournal-balitbang.kkp.go.id/index.php/bawal
e-mail:bawal.puslitbangkan@ gmail.com
BAWAL WIDYA RISET PERIKANAN TANGKAP
Volume 9 Nomor 1 April 2017
p-ISSN: 1907-8226
e-ISSN: 2502-6410
BAWAL
Nomor Akreditasi: 620/AU2/P2MI-LIPI/03/2015

\title{
HABITAT PEMIJAHAN DAN ASUHAN IKAN BILIH Mystacoleucus padangensis (Bleeker, 1852) DI SUNGAI NABORSAHAN, DANAU TOBA, SUMATERA UTARA
}

\section{SPAWNING AND NURSERY GROUND OF BILIH FISH Mystacoleucus padangensis (Bleeker, 1852) IN THE NABORSAHAN RIVER, TOBA LAKE, NORTH SUMATERA}

\author{
Ani Suryanti*1, Sulistiono², Ismudi Muchsin ${ }^{2}$ dan Endi Setiadi Kartamihardja ${ }^{3}$ \\ ${ }^{1}$ Mahasiswa Program Doktor Program Studi Pengelolaan Sumberdaya Perairan, Departemen MSP, Fakultas Perikanan dan Ilmu \\ Kelautan IPB, Jalan Raya Dramaga, Babakan, Dramaga, Babakan, Dramaga, Bogor, Jawa Barat 16680, Indonesia \\ ${ }^{2}$ Staf Pengajar Program Studi Pengelolaan Sumberdaya Perairan, Departemen MSP, Fakultas Perikaan dan Ilmu Kelautan IPB, Jalan \\ Raya Dramaga, Babakan, Dramaga, Babakan, Dramaga, Bogor, Jawa Barat 16680, Indonesia \\ ${ }^{3}$ Peneliti Utama Pusat Penelitian Pengelolaan Perikanan dan Konservasi Sumber Daya Ikan \\ Teregistrasi I tanggal: 06 Juni 2016; Diterima setelah perbaikan tanggal: 16 Juni 2017; \\ Disetujui terbit tanggal: 19 Juni 2017
}

\begin{abstract}
ABSTRAK
Ikan bilih (Mystacoleucus padangensis) merupakan salah satu ikan dari famili cyprinidae yang melakukan ruaya pemijahan dari danau menuju sungai. Habitat pemijahan dan asuhan ikan bilih perlu dikaji sebelum melakukan upaya pemulihan kembali ikan bilih di Danau Toba. Tujuan penelitian ini adalah untuk mengetahui habitat pemijahan dan habitat asuhan ikan bilih. Habitat pemijahan ditentukan berdasarkan jumlah ikan matang gonad dan habitat asuhan diidentifikasi berdasarkan keberadaan juvenil ikan bilih di Sungai Naborsahan, Danau Toba Sumatera Utara. Pengambilan sampel ikan bulanan (April 2013 sampai Mei 2014) dilakukan di enam stasiun yang ditentukan berdasarkan karakteristik sungai dan habitat ikan bilih. Ikan bilih matang gonad (siap mijah) dapat ditemukan di semua stasiun penelitian. Seluruh lokasi penelitian merupakan habitat pemijahan ikan bilih. Juvenil ikan bilih hanya ditemukan di stasiun 3, 4, 5 dan 6. Oleh karena itu, diduga stasiun 1 dan 2 merupakan daerah pemijahan bagi ikan bilih sedangkan stasiun 3, 4, 5, dan 6 merupakan daerah pemijahan sekaligus juga daerah asuhan ikan bilih.
\end{abstract}

Kata Kunci: Habitat pemijahan; asuhan; indeks gonadosomatik; juvenil; kelimpahan

\section{ABSTRACT}

Bilih fish (Mystacoleucus padangensis) is a species of the Cyprinidae family that have migration pattern from the lake to the river for spawning purpose. Spawning and nursery ground of bilih fish needs to be assessed before making a recovery effort of bilih fish in Lake Toba. The purpose of this study was to determine the nursery and spawning ground of bilih fish. Spawning ground is determined based on the number of mature gonad fishes and the nursery ground identified based on the presence of juvenile fishes in the Naborsahan River, Toba Lake, North Sumatra. The montly samples (April 2013 to May 2014) were collected from six stations that was determined based on the characteristics of the river and bilih fish habitat. The results showed that the mature gonad fish can be found at all research stations. The entire study sites are spawning habitat of bilih fish. The juvenile was found at the stations 3, 4,5 and 6. This phenomena suggests that the stations 1 and 2 possibly were only a spawning ground while the stations 3, 4, 5, and 6 were both the spawning and nursery ground of bilih fish.

Keywords: Spawning ground; nursery; Gonadosomatic index; juvenile; abundance 


\section{PENDAHULUAN}

Ikan Bilih (Mystacoleucus padangensis) merupakan salah satu ikan dari famili cyprinidae yang distribusinya sangat terbatas di Indonesia. Ikan ini tercatat sebagai ikan endemik Danau Singkarak Sumatera Barat Indonesia (Kottelat et al., 1993; Syandri, 1996; Kartamihardja \& Sarnita, 2010; Kartamihardja, 2009). Namun sejak tahun 2003 tercatat sebagai ikan yang berhasil diintroduksi di Danau Toba, Sumatera Utara, Indonesia (Kartamihardja \& Sarnita, 2010; Kartamihardja, 2009). Penyebaran ikan bilih terbatas hanya di Danau Singkarak dan Danau Toba. Ikan ini hidup di danau dan akan beruaya menuju sungai yang bermuara ke danau ketika akan melakukan pemijahan.

Hasil tangkapan ikan bilih (Mystacoleucus padangensis) di Danau Toba tercatat sebagai hasil tangkapan dominan sejak tahun 2005, bahkan pada tahun 2012 produksinya mencapai puncaknya yaitu 45.000 ton (Kartamihardja et al., 2013). Nilai tersebut sekitar dua kali lipat hasil tangkapan ikan lemuru di Selat Bali. Selama periode 2005-2012, nilai hasil tangkapan ikan bilih berkisar antara 155-255 milyar rupiah (Kartamihardja et al., 2013). Namun, sejak 2013 hasil tangkapan ikan bilih mulai menurun dan jauh menurun sangat drastis sejak awal tahun 2014 sehingga hasil tangkapan ikan bilih pada tahun 2014 diperkirakan kurang dari 1.000 ton (Kartamihardja et al., 2015).

Informasi reproduksi ikan bilih, habitat pemijahan dan asuhan ikan bilih di Danau Toba menjadi sangat penting ketika akan dilakukan upaya pemulihan kembali populasi ikan bilih di Danau Toba. Kajian biologi reproduksi ikan bilih yang sudah banyak dilakukan, tentang potensi dan status reproduksi, namun yang terkait dengan habitat pemijahan dan asuhan bagi ikan bilih baik di Danau Singkarak maupun di Danau Toba masih sangat terbatas. Kajian biologi reproduksi ikan bilih yang telah dilaporkan di Danau Singkarak meliputi fekunditas berkisar antara 2.155-5000 butir (Syandri 1993;1998), fekunditas antara 5.830-7.390 butir per ekor, atau 436-628 butir per gram bobot tubuh (Purnomo \& Sunarno 2009), fekunditas berkisar antara 880-4.723 butir (Patriono et al., 2010), fekunditas ikan bilih berkisar antara 6.907-9.355 butir (Syandri et al., 2013) dan indek gonadosomatik berkisar antara 6,0511,60\% (Junaidi 2005 dan Junaidi et al., 2009). Sedangkan kajian reproduksi ikan bilih di Danau Toba yang telah dilakukan mengenai, fekunditas, hubungan fekunditas dengan panjang total ikan bilih, diameter telur dan tingkat kematangan gonad. Kartamihardja \& Purnomo (2006), telah menganalisis fekuditas ikan bilih yang berkisar antara 3.654-14.561 butir dan terdapat hubungan antara fekunditas dengan panjang total ikan bilih dengan persamaan $\mathrm{F}=0,0237 * \mathrm{~L} 2,6463\left(\mathrm{R}^{2}=0,6114\right)$. Kartamiharja (2009) merekomendasikan empat sungai yang bermuara ke Danau Toba salah satunya adalah sungai Naborsahan sebagai daerah suaka perikanan. Kartamihardja \& Sarnita (2010) menyatakan bahwa fekunditas ikan bilih berkisar antara 3.654-14.561 butir dengan diameter telur berkisar antara 0,33-0,76 $\mu \mathrm{m}$ dan hubungan antar fekunditas dengan panjang total ikan bilih di Danau Toba mengikuti persamaan $\mathrm{F}=0,1964 * \mathrm{~L}^{4,2369},\left(\mathrm{R}^{2}=0,7432\right)$. Barus (2011) menyatakan bahwa hasil analisa tingkat kematangan gonad betina ikan bilih pada karamba jaring apung (KJA) dan muara sungai tertinggi ditemukan pada TKG V yaitu $34,00 \%$ dan $41,84 \%$. Umar \& Kartamihardja (2011) membahas mengenai fekunditas ikan bilih di Danau Toba tahun 2009 berkisar antara 4,568-15.812 butir dan tahun 2010 fekunditas berkisar 5.965-16.422 butir, hubungan fekunditas dengan panjang totoal ikan bilih pengamatan tahun 2009 meengikuti persamaan $\mathrm{F}=1,9577 * \mathrm{~L}^{3,3885},\left(\mathrm{R}^{2}=\right.$ $0,8781)$ dan pengamatan 2010 mengikuti persamaan $\mathrm{F}=$ $0,3369 * L^{4,0924},\left(R^{2}=0,9645\right)$. Hasil Penelitian Di Danau Singkarak Menunjuukan Bahwa Muara Sungai Merupakan Habitat Pemijahan Ikan Bilih (Syandri et al., 2013).

Habitat pemijahan dan asuhan ikan bilih terutama di Danau Toba juga belum pernah dilaporkan. Habitat tersebut merupakan habitat penting bagi mata rantai kelangsungan hidup ikan bilih. Informasi mengenai habitat pemijahan dan asuhan ikan bilih sangat diperlukan ketika akan dilakukan upaya pemulihan kembali populasi ikan bilih di Danau Toba yang saat ini mengalami penurunan cukup drastis. Oleh karena itu tujuan penelitian ini untuk mengetahui habitat pemijahan dan asuhan ikan bilih di Sungai Naborsahan Danau Toba Sumatera Utara.

\section{METODEPENELITIAN}

Penelitian ini dilakukan di Danau Toba dan Sungai Naborsahan Kecamatan Ajibata Kabupaten Toba Samosir Sumatera Utara. Pengambilan sampel ikan dilakukan pada enam stasiun yang ditentukan berdasarkan karakteristik sungai dan habitat ikan bilih (Tabel 1 dan Gambar 1). Pengambilan sampel dilakukan setiap bulan dari bulan April 2013 sampai Mei 2014. Analisis sampel dilakukan di Laboratorium Terpadu Manajemen Sumberdaya Perairan Fakultas Pertanian dan di Laboratorium Patologi Anatomi Fakultas Kedokteran, Universitas Sumatera Utara. 
Tabel 1. Posisi dan karakteristik stasiun penelitian ikan bilih di Sungai Naborsahan, Danau Toba, Sumatera Utara Table 1. The position and characteristics of research station the bilih fish in Naborsahan River, Lake Toba, North Sumatera

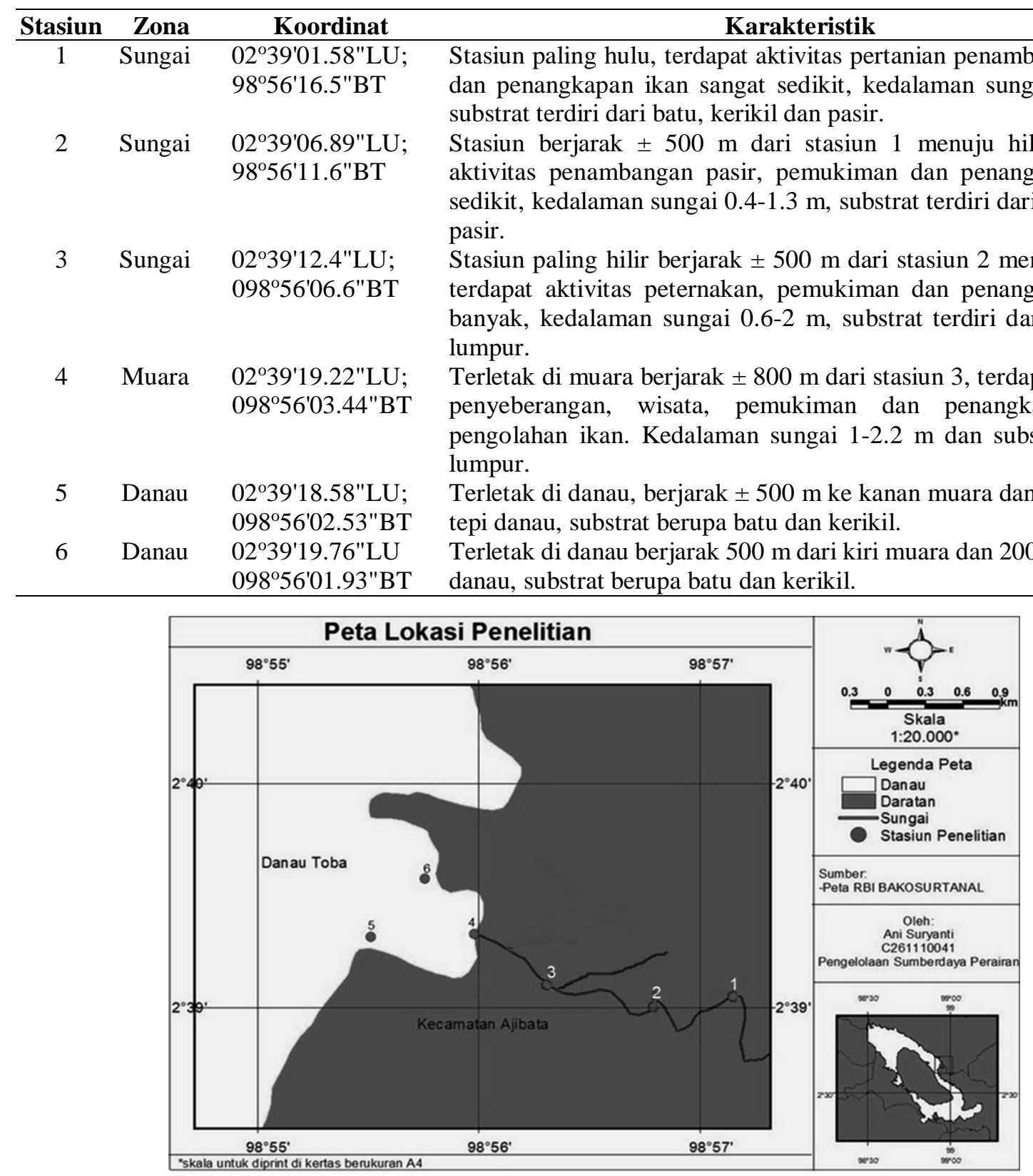

Gambar 1. Stasiun pengambilan sampel ikan bilih di Sungai Naborsahan Danau Toba Sumatera Utara.

Figure 1. Sampling station bilih fish in Naborsahan River Lake Toba North Sumatera.

Pengambilan sampel ikan dilakukan menggunakan jaring kantong dengan diameter mulut jaring 1,5 m panjang jaring $12 \mathrm{~m}$ dan mata jaring 0,79 inci, 0,59 inci serta 0,2 inci dipasang selama 5 jam dan jala tebar dengan diameter jaring $5 \mathrm{~m}$ dan mata jaring 1 inci. Jaring kantong dipasang selama 5 jam yang di sungai. Jala tebar dioperasikan di danau dengan 5-10 kali tebar (minimal diperoleh sampel 200 ekor tiap stasiun). Heupel et al., (2007) menyatakan bahwa daerah asuhan dapat diidentifikasi berdasarkan tiga kriteria, (1) kepadatan juvenil lebih besar daripada di daerah lain, (2) daerah yang cukup besar, dan (3) daerah asuhan digunakan berulang kali selama bertahun-tahun. Pada penelitian ini habitat asuhan diidentifikasi berdasarkan keberadaan juvenil dan anakan ikan bilih. Pengambilan sampel juvenil dan anakan menggunakan larva net yang dipasang tegak lurus melawan arus. Sampel ikan yang diperoleh langsung diidentifikasi melalui pengamatan karakter morfometrik identifikasi juvenil berdasarkan modifikasi Mekong River Comission (2013) dan ikan bilih berdasarkan Kottelat et al., (1993). Sampel 
diukur panjang total menggunakan jangka sorong dengan ketelitian $1 \mathrm{~mm}$ dan ditimbang bobot tubuh serta bobot gonadnya menggunakan timbangan elektrik dengan ketelitian 0,01 g. Pengamatan tingkat kematangan gonad dilakukan secara morfologi meliputi pengamatan anatomis berdasarkan ukuran, warna dan volume pada rongga perut dibedakan menjadi lima tahap (Brown-Peterson et al., 2011). Arocha dan Barrios (2009) menyatakan bahwa indek gonadosomatik dan persentase jumlah ikan matang gonad (siap mijah) dapat digunakan untuk menentukan musim pemijahan ikan. Kehadiran telur dan larva ikan di perairan juga dapat menjadi indikasi daerah pemijahan, meskipun harus dicatat bahwa tahap larva kemungkinan telah mengalami pergerakan dari daerah pemijahan. Larva dan juvenil juga dapat digunakan untuk menentukan musim pemijahan, daerah pemijahan dan daerah asuhan (El-Regal, 2013). Kehadiran betina matang gonad di daerah ruayanya dapat digunakan untuk mengidentifikasi daerah pemijahan (Tuggels, 1986). Daerah pemijahan pada ikan yang melakukan ruaya dapat ditentukan berdasarkan jumlah frekuensi betina matang gonad yang dinyatakan dalam persen di habitat ruayanya (Mbalassa et al., 2015). Ikan bilih merupakan ikan air tawar yang hidup di Danau dan beruaya menuju sungai yang bermuara ke danau untuk melakukan pemijahan (Kartamihardja \& Sarnita, 2010). Identifikasi Habitat pemijahan Ikan Bilih berdasarkan persentase jumlah ikan matang gonad juga pernah dilakukan oleh Syandri et al (2013). Identifikasi daerah pemijahan pada penelitian ini juga dilakukan berdasarkan jumlah ikan matang gonad yang ditemukan pada masingmasing stasiun. Identifikasi ikan matang gonad dilakukan berdasarkan analisis tingkat kematangan gonad (Tabel 2) dan Indek Gonadosomatik. Indek Gonadosomatik (IGS) ikan bilih dihitung berdasarkan rumus Effendie (1979) dengan rumus sebagai berikut:

$$
\begin{aligned}
& I S G=\frac{B g}{B t} X 100 \\
& \text { Keterangan: } \\
& \mathrm{IGS}=\text { Index Go.......... } \\
& \mathrm{Bg}=\text { bobot gonad }(\mathrm{g}) \\
& \mathrm{Bt}=\text { bobot tubuh ikan }(\mathrm{g})
\end{aligned}
$$

Tabel 2. Tingkat Kematangan Gonad (TKG) berdasarkan ciri morfologi ikan bilih di Sungai Naborsahan, Danau Toba, Sumatera Utara (Suryanti et al, 2015)

Table 2. The gonad developmental stages (GDS) based on morphology of bilih fish in Naborsahan River, Lake Toba, North Sumatera (Suryanti et al, 2015)

TKG Ciri morfologi

Tahap I tahap ini dapat ditemukan pada ikan bilih yang pernah memijah atau belum pernah memijah. (Immature) Secara morfologi ovarium berpasangan yang sangat kecil dan menempel dekat pada tulang belakang, sering nampak jelas dan kadang tampak seperti benang berwarna kelabu atau transparan, menyerupai pembuluh darah yang sangat tipis. Tahap ini merupakan tahap awal perkembangan sel telur atau sperma, sehingga pada tahap ini telur maupun sperma belum nampak.

Tahap II (pra merupakan tahap perkembangan, sedang berkembang, tapi tidak siap untuk memijah. Ovarium mature) secara morfologi terlihat seperti tabung kemerahan buram menempati hampir setengah rongga tubuh. Kapiler darah yang nyata di permukaan. Telur yang belum matang yang menyerupai bintik-bintik putih sudah mulai terlihat dengan mata telanjang. Testis sudah berwarna putih namun volumenya belum memenuhi rongga perut.

Tahap III pada tahap ini ikan sudah mampu memijah, pada masa perkembangan akhir dan fisiologis (maturing) mampu bertelur. Gonad betina (ovarium) maupun jantan (testis) mengisi hampir seluruh rongga tubuh. Ovarium yang abu kekuningan dan sperma berwarna putih, jika dilakukan striping akan keluar sel telur pada ikan betina dan mengeluarkan sperma pada ikan jantan.

Tahap IV merupakan tahap awal kemunduran, penghentian pemijahan. Bagian perut ikan nampak besar (mature) namun sangat lembek dan kosong, terkadang nampak warna kemerahan dan rongga yang melebar pada lubang genitalnya, hal ini mengindikasikan ikan baru saja mengeluarkan telur ataupun sperma. Ovarium dan testis yang lembek dan pembuluh darah yang menonjol, terkadang masih ada sisa sel telur atau sperma di dalam gonadnya .

Tahap V pada tahap seksual dewasa, aktif bereproduksi, ovarium kosong, longgar dan merah. Beberapa (spent) sisa-sisa telur dalam proses penyerapan kembali (resorpsi).

\section{HASIL DAN BAHASAN Hasil}

Sampel ikan bilih jantan yang diperoleh selama penelitian berjumlah 4.044 ekor dan betina berjumlah 2.025 ekor. Ikan jantan yang diperoleh memiliki kisaran panjang
45-184 mm dan bobot 1,12-47,7 g. Nisbah kelamin ikan bilih jantan dan betina berdasarkan lokasi penelitian berkisar antara 1,77-2,13 dan nisbah kelamin jantan dan betina matang gonad berkisar antara 3-3,5. 

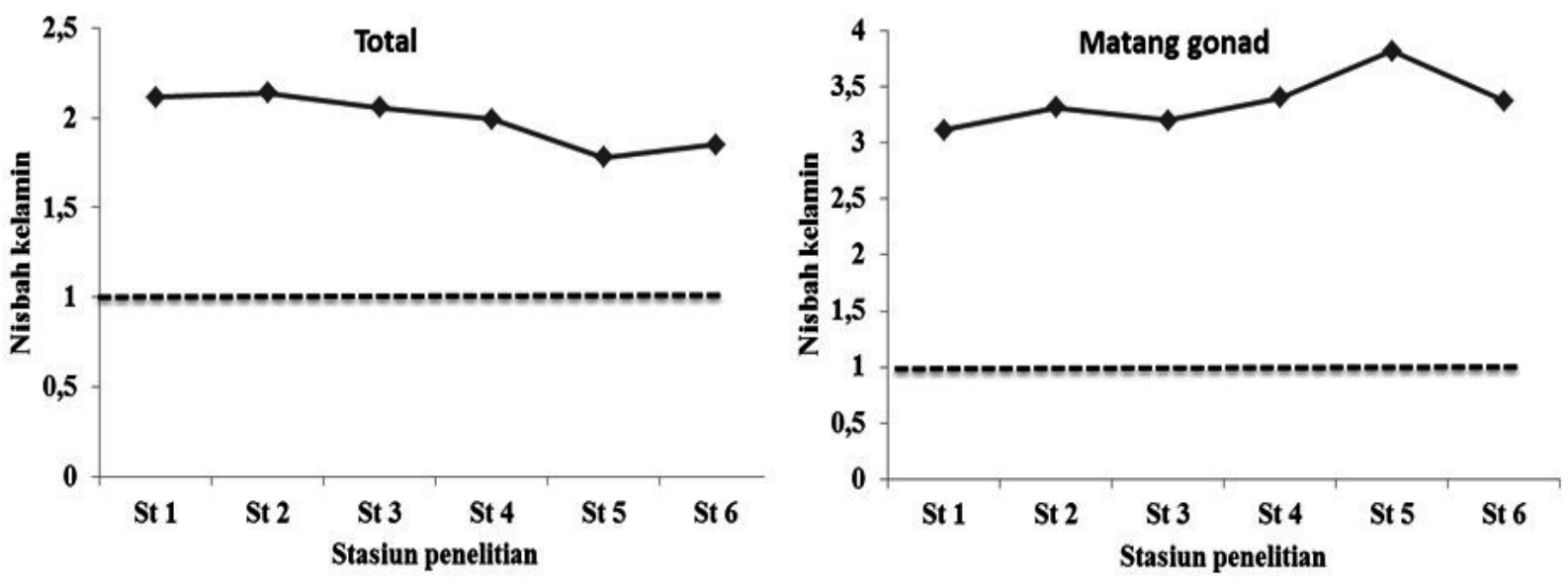

Gambar 2. Nisbah Kelamin ikan bilih Jantan dan betina di Sungai Naborsahan, Danau Toba, Sumatera Utara.

Figure 2. Sex ratio male and female of bilih fish in Naborsahan River Lake Toba, North Sumatera.

Nilai Indeks Gonadosomatik (IGS) bervariasi untuk ikan jantan berkisar antara 0,12-29,36\% dengan nilai ratarata berkisar 4,86-8,42\% dan ikan betina berkisar 0,12$31,70 \%$. Nilai rata-rata IGS pada masing-masing stasiun tidak begitu berfluktuasi dengan nilai rata-rata IGS berkisar antara 5,70-9,16\% (Gambar 3).

Ikan bilih yang diperoleh selama penelitian berada pada berbagai Tingkat Kematangan Gonad (TKG), dengan persentase TKG pada masing-masing stasiun dapat dilihat pada Gambar 4. Meskipun ikan bilih yang diperoleh selama penelitian berada pada berbagai TKG namun TKG III (matang Gonad) selalu mendominasi hasil tangkapan. Kondisi tersebut ditemukan baik pada ikan bilih jantan maupun ikan betina. Begitu juga dengan jumlah jantan

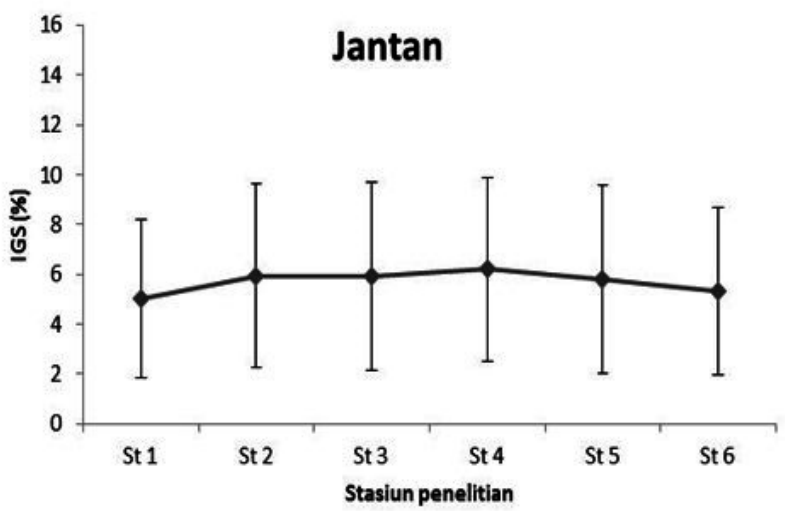

maupun betina matang gonad yang selalu ditemukan pada tiap stasiun penelitian dan jumlahnya selalu mendominasi. Jumlah jantan matang gonad berkisar antara 53,74-88,84\% dan jumlah betina matang gonad berkisar antara 20-68,89\% (Gambar 5).

Ikan bilih pada TKG IV merupakan ikan yang benarbenar baru saja melakukan pemijahan ditandani dengan bagian perut ikan nampak besar namun sangat lembek dan kosong, terkadang nampak warna kemerahan dan rongga yang melebar pada lubang genitalnya, juga ditemukan di seluruh stasiun penelitian. Jumlah ikan jantan yang baru saja memijah berkisar antara 3,46\%-15,47\% dan jumlah betina yang baru saja memijah berkisar antara 5,71\%-25,07\% (Gambar 5).

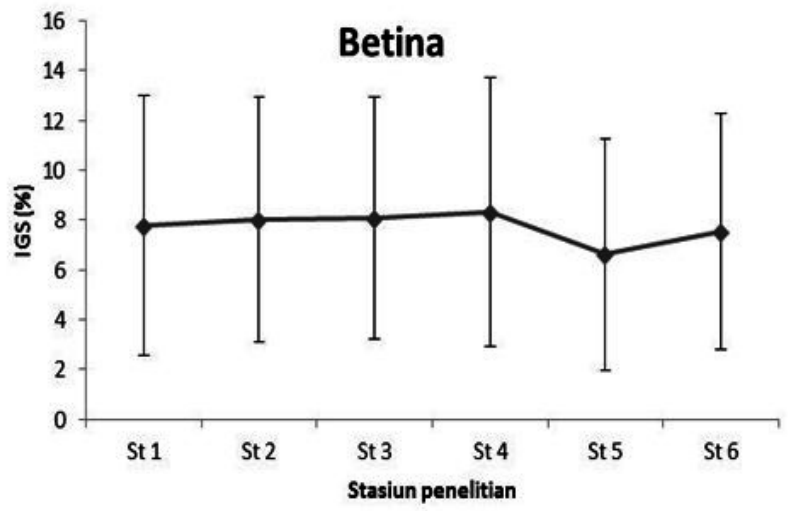

Gambar 3. Nilai rata-rata indeks gonadosomatik (IGS) ikan bilih jantan dan betina pada tiap stasiun penelitian di Sungai Naborsahan, Danau Toba, Sumatera Utara.

Figure 3. The average Gonadosomatic index (GSI) male and female of bilih fish in each research Naborsahan River Lake Toba, North Sumatera. 

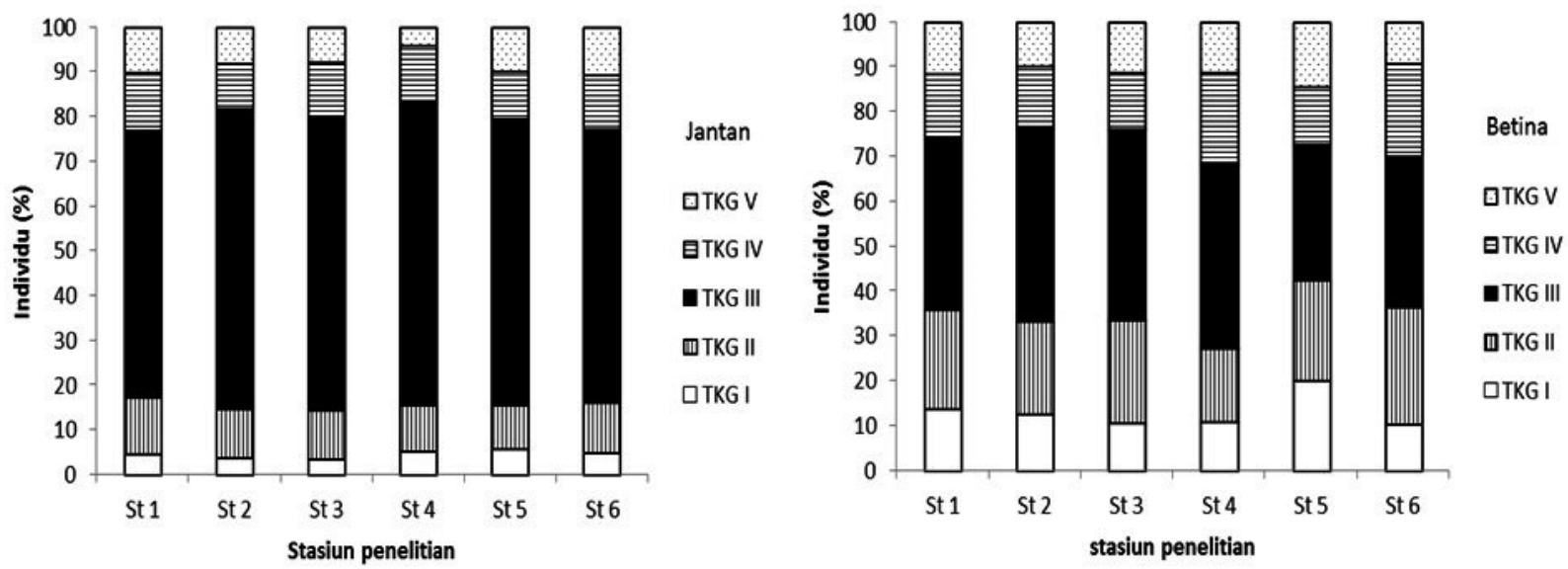

Gambar 4. Rata-rata persentase Tingkat Kematangan Gonad (TKG) ikan bilih pada tiap stasiun penelitian di Sungai Naborsahan, Danau Toba, Sumatera Utara.

Figure 4. The average percentage of Gonadal Development Stage (GDS) bilih fish at each research Naborsahan River Lake Toba North Sumatera.

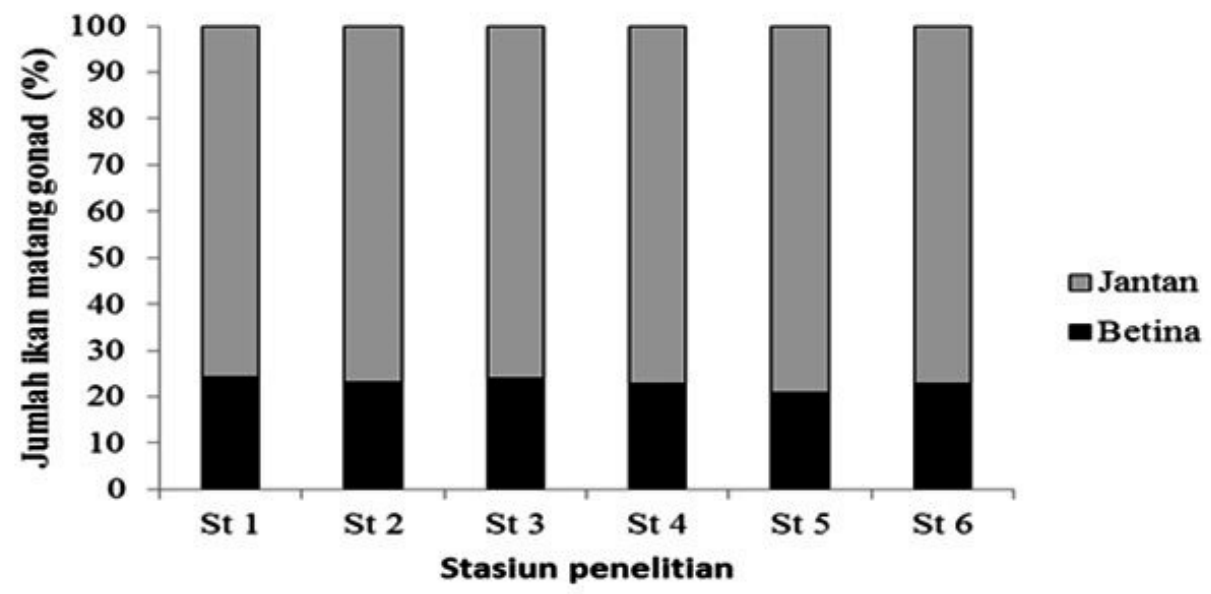

Gambar 5. Rata-raata jumlah ikan bilih matang gonad pada tiap stasiun penelitian di Sungai Naborsahan, Danau Toba, Sumatera Utara.

Figure 5. The average Number of bilih fish mature at each research station Naborsahan River Lake Toba North Sumatera.

Juvenil terbentuk setelah melalui fase larva, pada fase juvenil organ tubuh sudah mulai terbentuk secara sempurna dan pada fase ini secara morfologi mirip dengan ikan induk ikan bilih namun belum terbentuk organ reproduksi. Anakan atau benih ikan bilih organ tubuh sudah benar-benar sempurna, morfologinya sudah sama dengan induk ikan bilih hanya ukurannya yang masih kecil dan belum mencapai batas bawah ukuran pertama matang gonad. Suryanti (2015) menyatakan bahwa batas bawah ukuran pertama matang gonad ikan bilih di Sungai Naborsahan, Danau Toba adalah $78 \mathrm{~mm}$ pada ikan jantan dan betina $83 \mathrm{~mm}$. Jumlah sampel juvenil dan anakan yang diperoleh pada masing-masing stasiun berbeda jumlahnya. Pada stasiun 1 dan 2 tidak ditemukkan adanya juvenil dan anakan ikan bilih sedangkan di stasiun 3, 4, 5, dan 6 selalu ditemukkan juvenil dan anakan (Gambar 6). Jumlah juvenil dan jumlah anakan ikan bilih keberadaannya selalu beriiring. Ketika ditemukan juvenil jumlah dalam jumlah banyak, maka ditemukan anakan dalam jumlah yang banyak juga. Jumlah juvenil dan anakan yang paling banyak ditemukan pada stasiun 3 . 

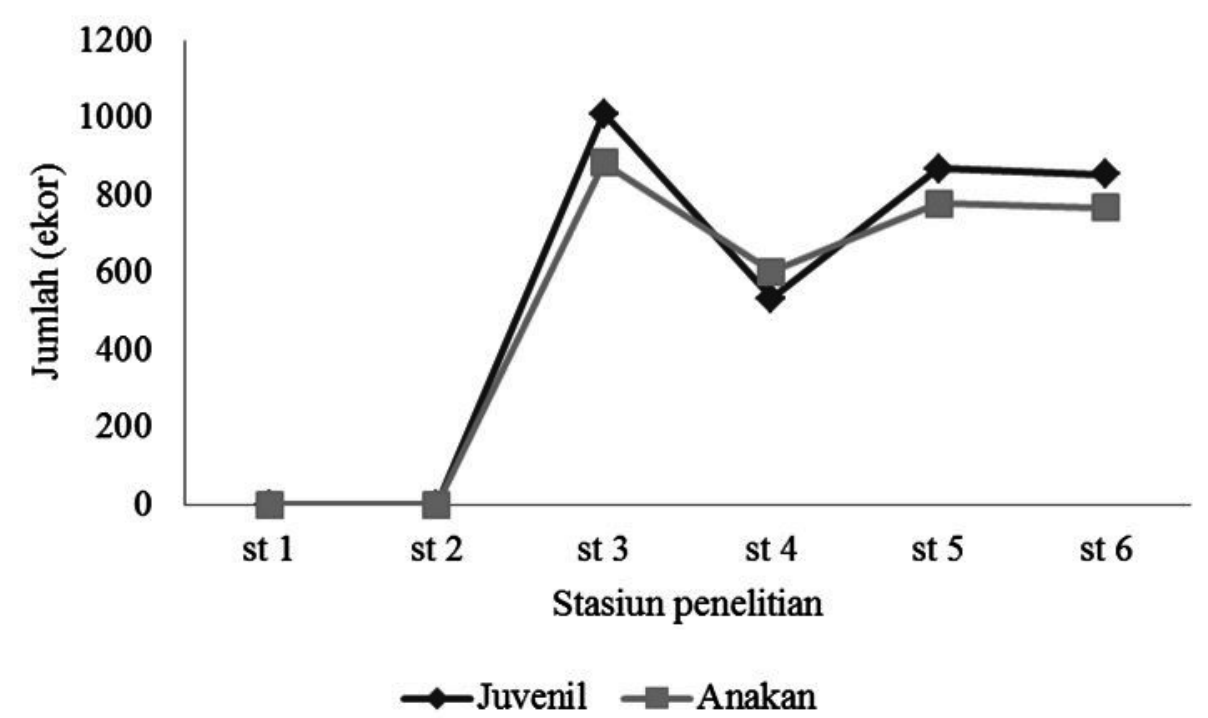

Gambar6. Jumlah juvenil dan anakan ikan bilih yang diperoleh pada tiap stasiun penelitian ikan bilih di Sungai Naborsahan, Danau Toba, Sumatera Utara.

Figure 6. The number of juvenile and young bilih fish at each station research in Naborsahan River Lake Toba North Sumatera.

\section{Bahasan}

Sampel ikan bilih yang diperoleh selama penelitian terdiri atas 4.044 ikan jantan dan 2.025 betina maka diperoleh nisbah kelamin 1:1,99. Nisbah kelamin ikan bilih yang diperoleh selama penelitian cenderung stabil pada tiap stasiun penelitian (Gambar 2). Effendie (1979) menyatakan bahwa kondisi ideal populasi ikan dalam suatu perairan dapat dilihat melalui perbandingan antara jumlah jantan dan jumlah betina dalam suatu populasi yang mengikuti rasio 1:1. Berdasarkan hal tersebut nisbah kelamin ideal selama penelitian pada tiap stasiun penelitian tidak pernah ditemukan. Nisbah kelamin akan bergeser dari rasio 1:1 karena faktor distribusi, aktivitas dan pergerakkan ikan (Turkmen et al., 2002). Nikolsky (1963) menyatakan bahwa ketersediaan makanan akan mempengaruhi nisbah kelamin, jika ketersediaan makanan berlimpah ikan betina menjadi dominan dan sebaliknya jantan akan dominan apabila makanan berkurang. Nisbah kelamin yang bervariasi dapat dijelaskan dari tingkah laku ikan terutama sifat menggerombolnya ikan yang berjenis kelamin sama pada habitat yang dikenalnya, yang berkaitan dengan responnya terhadap ketersediaan makanan dan keberadaan predator seperti yang terjadi pada ikan pelangi merah (Melanotaenia sp.) (Brown \& Warburton 1997; Brown 2001; Brown 2002; Brown 2003).

Menurut Ball \& Rao (1984), penyimpangan dari kondisi ideal nisbah kelamin ikan disebabkan oleh faktor tingkah laku reproduksi, kondisi lingkungan dan mortalitas penangkapan. Nisbah kelamin ikan bilih pada penelitian ini bergeser dari rasio 1:1 (Gambar 2) disebabkan oleh perilaku ikan bilih yang cenderung bergerombol ketika memasuki musim pemijahan dan ketika berada di habitat pemijahan. Kecenderungan ini terlihat pada jumlah jantan yang umumnya lebih banyak dari pada betina. Jumlah jantan pada masing-masing stasiun juga selalu lebih banyak dibandingkan betina. Begitu juga dengan jumlah ikan bilih matang gonad pada tiap stasiun, jantan selalu lebih banyak dibandingkan betina. Nisbah kelamin ikan bilih matang gonad di habitat pemijahan pada penelitian ini berkisar 3-3,5 yang berarti tiga sampai empat ekor ikan jantan membuahi satu ekor ikan bilih betina. Disamping hal tersebut juga menunjukkan bahwa lokasi penelitian merupakan habitat pemijahan bagi ikan bilih karena selalu ditemukan ikan bilih matang gonad pada tiap stasiun. Jumlah jantan yang ditemukan lebih banyak dibandingkan betina juga dapat dikatakan sebagai strategi reproduksi ikan bilih untuk menjamin keberhasilan pemijahan (Suryanti, 2015). Hal ini karena faktor lingkungan di alam selalu berubah-ubah, dengan jumlah jantan yang lebih banyak daripada betina akan memperbesar peluang keberhasilan pembuahan.

Hasil penelitian pada Gambar 3 memperlihatkan bahwa nilai rata-rata IGS ikan jantan fluktuasinya tidak terlalu tinggi yaitu pada kisaran 1,95-4,77\% sedangkan IGS betina berkisar 6,09-10,24\%. Nilai rata-rata IGS tertinggi ikan betina dapat ditemukan pada stasiun 4 dengan IGS 8,33\% dan terendah pada stasiun $5(6,62 \%)$. Nilai rata-rata IGS tertinggi ikan bilih betina pada penelitian ini sejalan dengan nilai rata-rata IGS tertinggi pada ikan jantan yaitu nilai rata-rata tertinggi ditemukan pada stasiun $4(5,38 \%)$ dan terendah dijumpai pada stasiun $5(4,64 \%)$. Ikan dewasa yang siap mengeluarkan telur atau sperma juga bisa menjadi indikasi daerah pemijahan (Ellis et al, 2012). Berdasarkan pernyataan tersebut menunjukkan bahwa seluruh stasiun penelitian merupakan habiat pemijahan 
bagi ikan bilih. Selalu ditemukannya ikan bilih yang baru saja melakukan pemijahan (TKG IV) dan ikan bilih yang sudah memijah (TKG V) juga membuktikan bahwa seluruh stasiun penelitian merupakan habitat pemijahan bagi ikan bilih.

Suryanti et al., (2016) menyatakan bahwa puncak pemijahan ikan bilih di sungai Naborsahan Danau Toba berlangsung pada Bulan Maret, ditandai dengan nilai IGS ikan bilih betina teringgi yang ditemukan pada Maret dan jumlah ikan matang gonad paling banyak juga ditemukan pada Bulan Maret. Nilai IGS dan persentase TKG III (siap mijah) tertinggi juga sejalan dengan jumlah betina matang gonad pada pada tiap stasiun penelitian jumlah jantan matang gonad yang diperoleh selalu lebih dari $50 \%$ (Gambar 4). Kondisi ini menunjukkan ikan bilih jantan siap melakukan pemijahan dan sekaligus juga membuktikan tiap stasiun penelitian merupakan daerah pemijahan bagi ikan bilih. Ikan bilih dengan TKG IV (mature) tertinggi dapat ditemukan pada stasiun 6 dan stasiun 4. Meskipun begitu ikan pada tahap ini merupakan ikan yang baru saja melakukan pemijahan dapat ditemukan pada tiap stasiun penelitian. Hal ini juga membuktikan bahwa seluruh stasiun penelitian merupakan habitat pemijahan bagi ikan bilih.

Hasil penelitian Syandri et al (2013) yang membandingkan antara muara sungai dengan bagian tengah danau memperlihatkan bahwa pada stasiun muara sungai Sumpur diperoleh ikan betina yang matang gonad sebanyak $68,37 \%$ dan jantan $78,31 \%$, dan di muara sungai Paninggahan diperoleh betina matang gonad sebanyak $78,31 \%$ dan jantan $73,39 \%$. Sedangkan di bagian tengah danau diperoleh betina matang gonad sebanyak $32,81 \%$ dan dan jantan 29,85\%. Tingginya persentase ikan bilih matang gonad di muara sungai tersebut berhubungan dengan sifat pemijahan ikan bilih yang melakukan ruaya dari danau ke sungai. Ikan bilih melakukan ruaya dari danau ke sungai adalah untuk memijah.

Persentase ikan bilih yang baru saja melakukan pemijahan TKG IV, jumlahnya lebih sedikit dari pada ikan yang siap memijah TKG III. Kondisi ini dimungkinkan karena ada perbedaan waktu puncak pemijahan harian ikan bilih di Danau Toba dan di Danau Singkarak. Syandri et al., (2013) yang melakukan pengamatan waktu pemijahan ikan bilih di Danau Singkarak antara pukul 16.00 - 24.00 WIB, menyampaikan bahwa ikan bilih melakukan pemijahan setiap hari dengan puncak pemijahan terjadi antara pukul 19.00-22.00 WIB dengan indikator jumlah ikan bilih yang memijah lebih dari $90 \%$. Kartamihardja \& Sarnita, (2010) melakukan pengamatan waktu pemijahan ikan bilih selama 24 jam dengan puncak pemijahan terjadi pada pagi hari antara pukul 05.00-09.00WIB. Pengambilan sampel pada penelitian ini dilakukan pada pagi hari yaitu pukul 05.00-08.00 WIB. Ikan bilih yang sudah memijah (TKG IV dan TKG V) selalu ditemukan pada tiap stasiun cukup membuktikan bahwa seluruh stasiun penelitian merupakan daerah pemijahan bagi ikan bilih.

Daerah di mana juvenil ditemukan dikenal dengan daerah asuhan. Daerah asuhan merupakan situs-situs di mana juvenil ditemukan pada kepadatan lebih tinggi, sedikit predasi dan memiliki pertumbuhan yang lebih cepat daripada di habitat lain, daerah asuhan mampu memberikan kontribusi relatif lebih besar untuk rekrutmen ikan dewasa dibandingkan dengan daerah yang bukan habitat asuhan (Ellis et al, 2012).

Berdasarkan hal tersebut membuktikan bahwa di stasiun 1 dan 2 bukan daerah asuhan bagi ikan bilih, karena di kedua stasiun ini tidak ditemukan adanya juvenil maupun anakan ikan bilih. Namun stasiun 1 dan 2 merupakan daerah pemijahan bagi ikan bilih didukung adanya ikan bilih matang gonad yang selalu ditemukkan pada kedua stasiun ini setiap waktu pengambilan sampel (Gambar 4 dan 5). Daerah asuhan bagi ikan bilih ada di stasiun 3, 4, 5, dan 6 karena pada keempat stasiun tersebut ditemukan adanya juvenil dan anakan ikan bilih. Stasiun 3,4,5,6 merupakan daerah pemijahan sekaligus juga daerah asuhan bagi ikan bilih.

Selalu ditemukannya ikan bilih matang gonad pada tiap stasiun penelitian mengindikasikkan lokasi penelitian di Sungai Naborsahan Danau Toba Sumatera Utara merupakan habitat pemijahan bagi ikan bilih. Keberadaan juvenil dan anakan ikan bilih di Sungai Naborsahan yaitu zona muara (stasiun 3 dan 4) dan danau (stasiun 5, dan 6) mengindikasikan habitat tersebut merupakan habitat yang cocok untuk daerah asuhan bagi ikan bilih. Habitat pemijahan dan habitat asuhan merupakan habitat penting bagi kelangsungan hidup ikan bilih maka direkomendasikan Sungai Naborsahan sampai bagian danau yang masih mendapat pengaruh dari muara sungai untuk ditetapkan sebagai kawasan konservasi bagi ikan bilih. Seluruh stasiun penelitian sebaiknya ditetapkan sebagai zona inti bagi konservasi sumberdaya ikan bilih, agar ikan bilih yang akan memijah tidak ditangkap oleh nelayan. Aktifitas penangkapan sebaiknya dilakukan di bagian danau yang jauh dari muara Sungai Naborsahan. Informasi ini sangat penting, guna menjaga kelestarian sumberdaya ikan bilih di Sungai Naborsahan dan meningkatkan produksi perikanan kedepannya. Penutupan aktivitas penangkapan ikan yang dilakukan di sungai, di muara, dan di bagian danau yang dekat dengan muara Sungai Naborsahan mutlak diperlukan untuk menjamin keberhasilan pemijahan dan asuhan bagi ikan bilih.

\section{KESIMPULAN}

Nisbah kelamin ikan bilih matang gonad di habitat pemijahan berkisar 3-3,5 yang berarti tiga sampai empat 
ekor ikan jantan membuahi satu ekor ikan bilih betina. Ikan bilih matang gonad (siap mijah) selalu mendominasi hasil tangkapan dan ikan bilih yang sudah memijah (TKG IV dan V) dapat ditemukan pada semua stasiun penelitian (stasiun 1, 2, 3, 4, 5, 6). Semua stasiun penelitian (stasiun 1, 2, 3, 4, 5 dan 6) merupakan daerah pemijahan bagi ikan bilih. Stasiun 1 dan 2 tidak ditemukan adanya juvenil dan anakan sedangkan stasiun 3, 4, 5 dan 6 ditemukan adanya juvenil dan anakan ikan bilih. Stasiun 3, 4, 5, dan 6 merupakan daerah pemijahan sekaligus juga daerah asuhan bagi ikan bilih. Mengingat pentingnya habitat pemijahan dan habitat asuhan ikan bilih maka direkomendasikan seluruh stasiun yaitu bagian Sungai Naborsahan dan bagian danau yang masih mendapat pengaruh dari muara sungai untuk ditetapkan sebagai kawasan konservasi sekaligus sebagai zona inti kawasan konservasi bagi ikan bilih.

\section{PERSANTUNAN}

Penelitian ini sebagian dananya dibiayai oleh Kementerian Keuangan melalui Lembaga Pengelola Dana Pendidikan Beasiswa Penelitian Disertasi. Penulis menyampaikan ucapan terima kasih kepada alumni Manajemen Sumberdaya Perairan Universitas Sumatera Utara (Hafiz, Vini, Melinda, Putri, Viktor, Reza, Green, Khair dan Rizki) yang telah membantu penelitan ini baik di lapangan maupun di laboratorium. Penulis juga mengucapkan terima kasih kepada nelayan Danau Toba (Bapak Perdana, Bapak Ferdi, Bapak Reldo dan Bapak Pahan) yang telah membantu dalam pengambilan sampel penelitian.

\section{DAFTAR PUSTAKA}

Arocha, F., \& Bárrios, A. (2009). Sex ratio, spawning seasonality, sexual maturity and feccundity of white marlin (Tetrapturus albidus) from the Western Central Atlantic. Fisheries Research. 95(1), 98-111.

Bal, D. V., \& Rao, K. V. (1984). Marine Fisheries (p. 250). New Delhi: Tata McGraw-Hill Publishing Company Limited.

Barus, S. R. D. (2011). Aspek ekobiologi ikan bilih (Mystacoleucus padangensis Bleeker) di perairan Danau Toba. Sumatera Utara. Master Tesis. Universistas Sumatera Utara. Medan.

Brown, C., Warburton, K. (1997). Predator recognition and anti predator responses in the rainbowfish (Melanotaenia eachamensis) Behav. Ecol. Sociobiol. 41,61-68.

Brown, C. (2001). Familiarity with the test environment improves escape responses in the crimson spotted rainbowfish (Melanotaenia duboulayi). Animal Cognition. 10(1), 1-10.

Brown, C. (2002). Do female rainbowfish (Melanotaenia spp) prefer to shoal with familiar individuals under predation pressure. J. Ethol. 20, 89-94.

Brown, C. (2003). Habitat-predator association and avoidance in rainbowfish (Melanotaenia spp). Ecology of Freshwater Fish. 12, 118-126.

Brown-Peterson, N. J., Wyanski, D. M., Saborido-Rey, F., Macewicz, B. J., Lowerre-Barbieri, S. K. (2011). A standardized terminology for describing reproductive development in fishes. Marine and Coastal Fisheries: Dynamics, Management, and Ecosystem Science. 3, 52-70.

Effendie, M. I. (1979). Metode Biologi Perikanan (p. 112). Bogor: Yayasan Dewi Sri.

Ellis, J. R., Milligan, S. P., Readdy, L., Taylor, N., \& Brown, M. J. (2012). Spawning and nursery grounds of selected fish species in UK waters. Sci. Ser. Tech. Rep., Cefas Lowestoft. 147, 56.

El-Regal, M. A. (2013). Spawning seasons, spawning grounds and nursery grounds of some Red Sea fishes. The Global Journal of Fisheries and Aqua. 6(6), 105125.

Heupel, M. R., Carlson, J. K. \& Simpf endorfer, C.A. (2007). Shark nursery areas: concepts, definition, characterization and assumptions. Marine Ecology Progress Series. 337, 287-297.

Junaidi, E. (2005). Kajian aspek reproduksi dan tingkat pemanfaatan ikan bilih (Mystacoleucus padangensis Blkr.) di Danau Singkarak dalam upaya konservasi insitu. Prosiding Forum Perairan Umum Indonesia ke 1 "Pemanfaatan dan Pengelolaan Perairan Umum secara Terpadu bagi Genussi Sekarang dan Mendatang (pp. 143-148). Jakarta, Indonesia: Departemen Kelautan dan Perikanan. Badan Riset Kelautan dan Perikanan, Pusat Riset Perikanan Tangkap.

Junaidi, E., Patriono, E., \& Sastra, F. (2009). Indeks gonad somatik ikan bilih (Mystacoleucus padangensis Blkr.) yang masuk ke muara sungai sekitar Danau Singkarak. Jurnal Penelitian Sains. 9,12-12

Kartamihardja, E. S., \& Purnomo, K. (2006). Keberhasilan introduksi ikan bilih (Mystacoleucus padangensis) ke habitatnya yang baru di Danau Toba. Sumatera Utara. Demersal. Dari Laut untuk Pembangunan. Prosiding 
Seminar Nasional Ikan IV (pp. 1-9). Jatiluhur Indonesia: Masyarkat Iktiologi Indonesia.

Kartamihardja, E. S. (2009). Pengelolaan Sumberdaya Ikan Bilih (Mystacoleucus padangensis) Introduksi di Danau Toba. J. Kebijak. Perikan. Ind. 1(2), 87-98.

Kartamihardja E. S., \& Sarnita, A. (2010). Populasi ikan bilih di Danau Toba-keberhasilan introduksi ikan, implikasi pengelolaaan dan prospek masa depan (p. 50). Cetakan edisi ke-2. Pusat Penelitian Pengelolaan Perikanan dan Konservasi Sumberdaya Ikan. Badan Penelitian dan Pengembangan Kelautan dan Perikanan Kementerian Kelautan dan Perikanan.

Kartamihardja, E. S., Umar, C., Prianto, E., Priatno, Y., Nasution, Z., \& Sadiyah, L. (2013). Naskah akademik rancangan peraturan daerah tentang pengelolaan perikanan dan konservasi sumberdaya ikan serta ekosistem Danau Toba secara bersama (p. 42). Jakarta: Puslit Pengelolaan Perikanan dan Konservasi Sumberdaya Ikan, Badan Litbang Kelautan dan Perikanan, KKP.

Kartamihardja E. S., Hedianto, D. A., \& Umar, C. 2015. Strategi Pemulihan Sumber Daya Ikan Bilih (Mystacoleucus Padangensis) Dan Pengendalian Ikan Kaca (Parambassis Siamensis) Di Danau Toba, Sumatera Utara. J. Kebijak. Perik. Ind. 7(2): 63-69.

Kottelat, M., Whitten, J. A., Kartikasari S. N., \& Wirjoatmodjo, S. (1993). Freshwater fishes of Western Indonesia and Sulawesi (p. 377). Hongkong: Periplus Edition (HK) Ltd.

Mbalassa, M., Nshombo, M., Kateyo, M. E., Chapman, L., Efitre, J., \& Bwanika, G. (2015). Identification of migratory and spawning habitats of Clarias gariepinus (Burchell, 1822) in Lake Edward-Ishasha River watershed, Albertine Rift Valley, East Africa. International Journal of Fisheries and Aquatic Studies. 2(3), 128-138.

Mekong River Commission. (2013). A guide to larvae and juveniles of some common fish species from the Mekong River Basin. MRC Technical Paper. (38), 235.

Nikolsky, G. V. (1963). The Ecology of Fishes (p. 432). New York: Academy press.

Patriono, E., Junaidi, E., \& Sastra F. (2010). Fekunditas Ikan Bilih (Mystacoleucus padangensis Blkr.) di Muara Sungai Sekitar Danau Singkarak. J. Penelitian Sains. 13(3), 55-58.
Purnomo, K., \& Sunarno, M. T. (2009). Beberapa aspek biologi ikan bilih (Mystacoleucus padangensis) di Danau Singkarak, Sumatera Barat. Bawal, Widya Riset Perikanan Tangkap. 2(6), 265-271.

Suryanti, A. (2015). Ekobiologi ikan bilih Mystacoleucus padangensis (Bleeker 1852) sebagai dasar pengelolaan di Danau Toba, Sumatera Utara. PhD Thesis. Institut Pertanian Bogor.

Suryanti, A., Sulistiono., Muchsin I., \& Kartamihardja E. S. (2016). Reproductive Biology of Female Bilih Fish (Mystacoleucus padangensis Bleeker 1852) in Naborsahan River Toba Lake, North Sumatera, Indonesia. Asian Journal of Developmental Biology. $1-12$.

Syandri, H. (1996). Aspek reproduksi ikan bilih Mystacoleucus padangensis Bleeker dan kemungkinan pembenihannya di danau Singkarak. PhD Thesis. Institut Pertanian Bogor.

Syandri, H. (1993). Potensi reproduksi ikan bilih, Mystacoleucus padangensis Blkr di Danau Singkarak. Fisheries Journal Garing. 3(4), 22-28.

Syandri, H. (1998). Fekunditas, makanan dan habitat pemijahan ikan bilih (Mystacoleucus padangensis Blkr) di Danau Singkarak. Jurnal Iptekni. 2(5), 61-72.

Syandri, H., Azrita., \& Aryani, N. (2013). Distribusi ukuran, reproduksi dan habitat pemijahan ikan bilih (Mystacoleucus padangensis Blkr.) di Danau Singkarak. Bawal. 5(1), 1-8.

Turkmen, M., Erdogan O., Yildirim, A., \& Akhyurt, I. (2002). Reproductive tactics, age and growth of Capoeta capoeta umla Heckel 1843 from the Askale region of the Karasu River, Turkey. J Fish Res. 54,317-328.

Teugels, G. G. (1986). A systematic revision of the African species of the genus Clarias (Pisces; Clariidae). Ann Mus R Afr Centr Sci Zool. 247:199.

Umar, C., \& Kartamihardja E. S. (2011). Hubungan panjangberat. kebiasaan makan dan kematangan gonad Ikan Bilih (Mystacoleucus padangensis Bleeker) di Danau Toba. Sumatera Utara. Bawal. 3(6), 351-356. 